\title{
Effect of Salicylic Acid Foliar Spray and NPK Fertilization on Wheat Productivity
}

\author{
Shalaby, E.M1 ; E.A. Ali ${ }^{1}$; E.A. Abd El-Lattief ${ }^{2}$ and Asmaa A. Hamdallah ${ }^{1}$ \\ ${ }^{1}$ Agron. Dept., Agric. Fac., Assiut Univ. \\ ${ }^{2}$ Agron. Dept., Agric. Fac., South Valley Univ. \\ Received on: $20 / 8 / 2017$ \\ Accepted for publication on: 23/8/2017
}

\section{Abstract}

A field experiment was carried out at the Experimental Farm, Agriculture Faculty, South Valley University at Qena Governorate, Egypt, during 2013/2014 and 2014/2015 seasons to study the effect of salicylic acid and NPK fertilization on wheat productivity. The experiment was laid out in a randomized complete block design (RCBD) using strip plot arrangement with three replications. The first variable was salicylic acid concentrations which occupied horizontally. While the second one was NPK rates which allocated vertically. The obtained results showed that all studied traits in both seasons were affected significantly by salicylic acid concentrations in favour of $150 \mathrm{ppm}$ concentration as well as by NPK fertilization rates in favour of high rate $\left(125,45\right.$ and $48 \mathrm{~kg} \mathrm{fed}^{-1}$ of $\mathrm{N}, \mathrm{P}$ and $\mathrm{K}$, respectively). Furthermore, wheat plants sprayed by high salicylic acid concentration and subjected to high NPK fertilization rate produced the highest mean values of grain yield (2600 and $2520 \mathrm{~kg} \mathrm{fed}^{-1}$ in the first and second seasons, respectively). While, wheat plants sprayed by high salicylic acid concentration and subjected to low NPK fertilization rate gave the maximum mean values of use efficiency for nitrogen, phosphorus and potassium in both seasons.

\section{Keywords: Salicylic acid, NPK fertilization, wheat.}

\section{Introduction}

Wheat (Triticumspp. L.) crop consider is one of the most important cereal crops in the world with regard to cultivated area and total production. The cultivated area of wheat in Egypt during 2016 season was about 3.0 million fed. with the total yield production of 8.1 million metric tonswhile the total consumption reached about 19.7 million metric tons (USDA,2017). So, increasing wheat production in order to reduce the gap between production and consumption are the strategic aim. As land and water resources are limited in Egypt, increasing the productivity of wheat from the unit area is an important part in increasing the total production. Such target will be achieved by in- creasing the cultivated area, cultivating high yield varieties, and adoption of improved cultural practices.

Salicylic acid (SA), a naturally occurring plant hormone, acts as an endogenous signal molecule responsible for inducing a biotic stress tolerance in plants (Raskin, 1992 and Gunes et al., 2007) Exogenous application of SA may participate in the regulation of physiological processes in plants, such as stomata closure, ion uptake and transport membrane permeability and photosynthesis and growth. Salicylic acid treatment affected the nutrient balances in the plant as reported by Borsani et al. (2001) who emphasized that exogenous application of SA resulted in a significant increase in plant growth 
both in saline and non-saline conditions. Also, Al-Hakimi and Hamada (2001) shown that salicylic acid (SA) plays a role in the response of plants to salt and osmotic stresses. Generally, deficiency or very high levels of SA increases the plant susceptibility to abiotic stress. Egypt is considered to be a heavy user of chemical fertilizers, especially $\mathrm{N}$ fertilizers then $\mathrm{P}$ and $\mathrm{K}$ fertilizers. Soil fertility continues to decline because of combined effects of increasing pressure for land use for crop production, inadequate compensation of nutrients exported and lack of nutrients management. The combined application of N, P and $\mathrm{K}$ has proved to be more effective in increasing yield of wheat as compared to sole application of either $\mathrm{N}$ or P or K (Petkov, 1983). Different NPK levels significantly affected wheat plant height, Number offertile tillers, 1000-grain weight, grain yield and grain protein content of wheat (Hussain et al., 2002; Rehman et al., 2008 and Leghari et al., 2016.

Therefore, this work designed to investigate the response of wheat plants to exogenous application of different concentrations of salicylic acid and NPK fertilization.

\section{Materials and Methods}

Experimental site description:

A field experiment was carried out at the Experimental Farm, Agriculture Faculty, South Valley University at Qena Governorate, Egypt, during 2013/2014 and 2014/2015 seasons to study the effect of salicylic acid and NPK fertilization on wheat productivity. The farm is located at an altitude of $79 \mathrm{~m}$ above sea level and is intersected by $26^{\circ} 10^{\prime} \mathrm{N}$ latitude and $32^{\circ} 43^{\prime} \mathrm{E}$ longitude. The soil of the experimental site is sandy-loam throughout its profile $(74.4 \%$ sand, $15.8 \%$ silt and $9.8 \%$ clay), with a $\mathrm{pH}$ value of $7.77,2.62 \mathrm{EC}\left(\mathrm{dSm}^{-1}\right)$, $0.42 \%$ organic matter content, $0.34 \%$ total $\mathrm{N}, 7.98,186 \mathrm{ppm}$ available $\mathrm{P}$ and $\mathrm{K}$, respectively.

Experimental treatments and design:

The experiment was carried out in a randomized complete block design (RCBD) using strip plot arrangement with three replications. The first variable was salicylic acid (SA) concentrations $(0,50,100$ 1nd $150 \mathrm{ppm}$ ) which occupied horizontally. While the second variable was NPK rates which allocated vertically. Three rates of NPK were studied as follows:

1- Low rate of NPK fertilizers $\left(75,15\right.$ and $24 \mathrm{~kg} \mathrm{fed}^{-1}$ of N. P and $\mathrm{K}$, respectively).

2- Recommended rate of NPK fertilizers $\left(100,30\right.$ and $36 \mathrm{~kg}^{-1} \mathrm{fed}^{-1}$ of $\mathrm{N}, \mathrm{P}$ and $\mathrm{K}$, respectively).

3- High rate of NPK fertilizers $\left(125,45\right.$ and $48 \mathrm{~kg} \mathrm{fed}^{-1}$ of $\mathrm{N}, \mathrm{P}$ and $\mathrm{K}$, respectively).

\section{Cultural practices:}

Bread wheat (Giza $168 \mathrm{cv}$.) was sown on the $25^{\text {th }}$ of November in both seasons. Sprayings of SA were done 45 days after sowing. The NPK fertilizerswas applied in the form of Ammonium nitrate (33.5\% $\mathrm{N})$, Calcium super phosphate $(15.5 \%$ $\left.\mathrm{P}_{2} \mathrm{O}_{5}\right)$ and potassium sulphate $\left(48 \% \mathrm{~K}_{2} \mathrm{O}\right)$ as a source of nitrogen, phosphorus and potassium, respectively.Calcium super phosphate $\left(15.5 \% \quad \mathrm{P}_{2} \mathrm{O}_{5}\right)$ was added during soil preparation. While, nitrogen fertilizer was applied in three equal doses before the first, second and third irriga- 
tion, respectively. Potassium sulphate $\left(48 \% \mathrm{~K}_{2} \mathrm{O}\right)$ was added before third irrigation. The experimental soil site was fallow in the summer season. All other cultural practices were carried out as recommended for wheat crop.

\section{Measured traits:}

At harvest ten guarded stems for each experimental unit were taken and plant height $(\mathrm{cm})$, spike length $(\mathrm{cm})$, number of kernels spike ${ }^{-1}$ and kernels weight spike $^{-1}$ were determined. 1000-kernel weight, biological, grain and straw yields were determined in plot basis. The use efficiency of $\mathrm{N}, \mathrm{P}$ and $\mathrm{K}$ applied to wheat was judged by the quantity of grain yield produced per kg N, P and $\mathrm{K}$ applied $\left(\mathrm{Kg} \mathrm{Kg}^{-1}\right)$ according Ali (2010).

\section{Statistical analysis:}

All collected data were analyzed with analysis of variance (ANOVA) Procedures using the SAS Statistical Software Package (v.9.2, 2008). Differences between means were compared by LSD at 5\% level of significant (Gomez and Gomez, 1984).

\section{Results and Discussions}

\section{A- Vegetative traits:}

Plant height (cm)

Data presented in Table 1 show that salicylic acid, NPK fertilization and their interaction had a significant effect on plant height of bread wheat cv Giza 168 in the two growing seasons. All studied salicylic acid concentrations enhancement this trait compared to control (without sali- cylic acid) in favor of $150 \mathrm{ppm}$ concentration (high concentration) which gained the highest mean values of plant height $(86.30$ and $80.93 \mathrm{~cm}$ in the first and second seasons, respectively).Salicylic acid treatment affected the nutrient balances in the plant as reported by Borsani et al. (2001) who emphasized that exogenous application of SA resulted in a significant increase in plant growth under different conditions. The same trend was obtained by Raskin (1992) and Gunes et al. (2007). Furthermore, the high NPK fertilization rate produced the highest mean values of plant height which were 87.06 and $78.60 \mathrm{~cm}$ in the first and second seasons, respectively. This may be due to the role of NPK nutrients in cell elongation and division as well as increases in photosynthesis process. These findings are in a good line with those obtained by Hussain et al. (2002), Rehman et al. (2008) and Leghari et al. (2016). Moreover, the interaction between salicylic acid and NPK fertilization had a significant influence on plant height in both seasons. Thus, the highest mean values of plant height (94.77 and $85.40 \mathrm{~cm}$ in the first and second seasons, respectively) were obtained from wheat plants sprayed with $150 \mathrm{ppm}$ salicylic acid and fertilized with 125,45 and $48 \mathrm{~kg} \mathrm{fed}^{-1}$ of $\mathrm{N}, \mathrm{P}$ and $\mathrm{K}$, respectively. 
Table 1. Effect of salicylic acid, NPK fertilizations and their interaction on Plant height(cm)

\begin{tabular}{|c|c|c|c|c|c|c|c|c|c|c|}
\hline Seasons & \multicolumn{5}{|c|}{ 2013-2014 } & \multicolumn{5}{|c|}{ 2014-2015 } \\
\hline Salicylic acid NPK & 0 & 50 & 100 & 150 & Mean & 0 & 50 & 100 & 150 & Mean \\
\hline Low & 70.05 & 73.50 & 77.12 & 80.00 & 75.17 & 68.85 & 69.80 & 75.00 & 77.50 & 72.79 \\
\hline Recommended & 71.35 & 75.90 & 87.25 & 84.12 & 79.66 & 69.10 & 71.00 & 77.00 & 79.90 & 74.25 \\
\hline High & 75.30 & 88.15 & 90.00 & 94.77 & 87.06 & 73.80 & 75.00 & 80.20 & 85.40 & 78.60 \\
\hline Mean & 72.23 & 79.18 & 84.79 & 86.30 & ---- & 70.58 & 71.93 & 77.40 & 80.93 & ---- \\
\hline $\begin{array}{l}\text { F test and } \\
\text { LSD }_{0.05} \text { value }\end{array}$ & \multicolumn{3}{|c|}{$\mathrm{F}$ test } & \multicolumn{2}{|c|}{ LSD } & \multicolumn{3}{|c|}{$\mathrm{F}$ test } & \multicolumn{2}{|c|}{ LSD } \\
\hline SA & \multicolumn{3}{|c|}{$*$} & \multicolumn{2}{|c|}{2.05} & \multicolumn{3}{|c|}{ * } & \multicolumn{2}{|c|}{0.93} \\
\hline NPK & \multicolumn{3}{|c|}{$*$} & \multicolumn{2}{|c|}{1.162} & \multicolumn{3}{|c|}{ * } & \multicolumn{2}{|c|}{1.1} \\
\hline SA*NPK & \multicolumn{3}{|c|}{$*$} & \multicolumn{2}{|c|}{2.20} & \multicolumn{3}{|c|}{ * } & \multicolumn{2}{|c|}{1.90} \\
\hline
\end{tabular}

Where, *mean significant at $5 \%$ level of significant

Low $=75,15$ and $24 \mathrm{~kg} \mathrm{fed}^{-1}$ of $\mathrm{N}, \mathrm{P}$ and $\mathrm{K}$, respectively

Recommended $=100,30$ and $36 \mathrm{~kg} \mathrm{fed}^{-1}$ of N, P and K, respectively

High $=125,45$ and $48 \mathrm{~kg} \mathrm{fed}^{-1}$ of N, P and K, respectively

\section{Spike length (cm)}

Data presented in Table 2 focus that salicylic acid, NPK fertilization and their interaction had a significant effect on spike length of bread wheat cv Giza 168 in the two growing seasons. All studied salicylic acid concentrations enhancement this trait compared to control (without salicylic acid) in favor of $150 \mathrm{ppm}$ concentration (high concentration) which gained the highest mean values of spike length $(10.77$ and $10.30 \mathrm{~cm}$ in the first and second seasons, respectively). Salicylic acid treatment affected the nutrient balances in the plant as reported by Borsani et al. (2001) who emphasized that exogenous application of SA resulted in a significant increase in plant growth both in saline and non-saline conditions. The same trend was obtained by Raskin (1992) and Gunes et al.
(2007). Furthermore, the high NPK fertilization rate produced the highest mean values of spike length which were 11.04 in the first seasons, and 10.30 in the second one. This may be due to the role of NPK nutrients in cell elongation and division as well as increases in photosynthesis process. These findings are in a good line with those obtained by Hussain et al. (2002), Rehman et al. (2008) and Leghari et al. (2016). Moreover, the interaction between salicylic acid and NPK fertilization had a significant influence on spike length in both seasons. Thus, the highest mean values of spike length $(11.80$ and $11.00 \mathrm{~cm}$ in the first and second seasons, respectively) were obtained from wheat plants sprayed by $150 \mathrm{ppm}$ salicylic acid and fertilized with 125, 45 and $48 \mathrm{~kg} \mathrm{fed}^{-1}$ of $\mathrm{N}, \mathrm{P}$ and $\mathrm{K}$, respectively. 
Table 2. Effect of salicylic acid, NPK fertilizations and their interaction onspike length (cm)

\begin{tabular}{|c|c|c|c|c|c|c|c|c|c|c|}
\hline Seasons & \multicolumn{5}{|c|}{ 2013-2014 } & \multicolumn{5}{|c|}{ 2014-2015 } \\
\hline Salicylic acid NPK & 0 & 50 & 100 & 150 & Mean & 0 & 50 & 100 & 150 & Mean \\
\hline Low & 9.10 & 9.35 & 9.50 & 10.00 & 9.49 & 8.76 & 9.55 & 9.85 & 9.90 & 9.52 \\
\hline Recommended & 10.00 & 9.50 & 10.00 & 10.50 & 10.00 & 9.25 & 9.75 & 9.95 & 10.00 & 9.74 \\
\hline High & 10.55 & 10.80 & 11.00 & 11.80 & 11.04 & 9.70 & 10.00 & 10.50 & 11.00 & 10.30 \\
\hline Mean & 9.88 & 9.88 & 10.17 & 10.77 & ------ & 9.24 & 9.77 & 10.10 & 10.30 & ----- \\
\hline $\begin{array}{l}\text { F test and } \\
\mathrm{LSD}_{0.05} \text { value }\end{array}$ & \multicolumn{3}{|c|}{$F$ test } & \multicolumn{2}{|c|}{ LSD } & \multicolumn{3}{|c|}{$\mathrm{F}$ test } & \multicolumn{2}{|c|}{ LSD } \\
\hline SA & \multicolumn{3}{|c|}{ * } & \multicolumn{2}{|c|}{0.13} & \multicolumn{3}{|c|}{ * } & \multicolumn{2}{|c|}{0.10} \\
\hline NPK & \multicolumn{3}{|c|}{ * } & \multicolumn{2}{|c|}{0.22} & \multicolumn{3}{|c|}{ * } & \multicolumn{2}{|c|}{0.19} \\
\hline SA*NPK & \multicolumn{3}{|c|}{$*$} & \multicolumn{2}{|c|}{0.25} & \multicolumn{3}{|c|}{ * } & \multicolumn{2}{|c|}{0.23} \\
\hline
\end{tabular}

Where, *mean significant at $5 \%$ level of significant

Low $=75,15$ and $24 \mathrm{~kg} \mathrm{fed}^{-1}$ of $\mathrm{N}, \mathrm{P}$ and $\mathrm{K}$, respectively

Recommended $=100,30$ and $36 \mathrm{~kg} \mathrm{fed}^{-1}$ of N, P and K, respectively

$\mathrm{High}=125,45$ and $48 \mathrm{~kg} \mathrm{fed}^{-1}$ of $\mathrm{N}, \mathrm{P}$ and $\mathrm{K}$, respectively

\section{B-Yield components:}

Number of kernels spike ${ }^{-1}$

Illustrated data in Table 3 reveal that salicylic acid, NPK fertilization and their interaction had a significant effect on the number of kernels spike $^{-1}$ in both seasons. Increasing salicylic acid concentration from 50 to $150 \mathrm{ppm}$ increased significantly number of kernels spike ${ }^{-1}$ by 17.14 and $20.30 \%$ in the first and second seasons, respectively. This is to be logic since the same trend was observed with regard to spike length. These results are in harmony with that obtained by Ibrahim et al. (2014). Also, the high rate of NPK fertilization produced the highest mean values of kernels number spike $^{-1} \quad(53.50$ and 51.25 kernel spike $^{-1}$ in the first and second seasons, respectively). This is may be due to the longest spikes produced by the same NPK fertilizer rates which led to an increase in spikelets number and consequently increased number of kernels spike ${ }^{-1}$. Similar trend was observed by Rehman et al. (2008) and Ibrahim et al (2014). Here too, the highest mean values of kernel number spike ${ }^{-1}$ were recorded from $150 \mathrm{ppm}$ salicylic acid with high NPK fertilization rate in both seasons which gained 60.00 and 58.00 kernel spike $^{-1}$ in the first and second seasons, respectively.

Table 3. Effect of salicylic acid, NPK fertilizations and their interaction onnumber of kernel spike ${ }^{-1}$

\begin{tabular}{|c|c|c|c|c|c|c|c|c|c|c|}
\hline Seasons & \multicolumn{5}{|c|}{ 2013-2014 } & \multicolumn{5}{|c|}{ 2014-2015 } \\
\hline Salicylic acid NPK & 0 & 50 & 100 & 150 & Mean & 0 & 50 & 100 & 150 & Mean \\
\hline Low & 37.00 & 41.00 & 49.00 & 50.00 & 44.25 & 35.00 & 39.00 & 46.00 & 50.00 & 42.50 \\
\hline Recommended & 39.00 & 45.00 & 50.00 & 54.00 & 47.00 & 38.00 & 44.00 & 49.00 & 52.00 & 45.75 \\
\hline High & 43.00 & 54.00 & 57.00 & 60.00 & 53.50 & 42.00 & 50.00 & 55.00 & 58.00 & 51.25 \\
\hline Mean & 39.67 & 46.67 & 52.00 & 54.67 & $\begin{array}{ll}--- \\
\end{array}$ & 38.33 & 44.33 & 50.00 & 53.33 & $\begin{array}{l}---- \\
\end{array}$ \\
\hline $\begin{array}{l}\text { F test and } \\
\text { LSD }_{0.05} \text { value }\end{array}$ & \multicolumn{3}{|c|}{$\mathrm{F}$ test } & \multicolumn{2}{|c|}{ LSD 0.05} & \multicolumn{3}{|c|}{$\mathrm{F}$ test } & \multicolumn{2}{|c|}{ LSD 0.05} \\
\hline SA & \multicolumn{3}{|c|}{$* *$} & \multicolumn{2}{|c|}{2.50} & \multicolumn{3}{|c|}{$* *$} & \multicolumn{2}{|c|}{1.60} \\
\hline NPK & \multicolumn{3}{|c|}{$* *$} & \multicolumn{2}{|c|}{2.16} & \multicolumn{3}{|c|}{$* *$} & \multicolumn{2}{|c|}{1.30} \\
\hline SA*NPK & \multicolumn{3}{|c|}{$* *$} & \multicolumn{2}{|c|}{2.80} & \multicolumn{3}{|c|}{$* *$} & \multicolumn{2}{|c|}{1.80} \\
\hline
\end{tabular}

Where, $* *$ mean significant at $1 \%$ level of significant

Low $=75,15$ and $24 \mathrm{~kg} \mathrm{fed}^{-1}$ of N, P and $\mathrm{K}$, respectively

Recommended $=100,30$ and $36 \mathrm{~kg} \mathrm{fed}^{-1}$ of $\mathrm{N}, \mathrm{P}$ and $\mathrm{K}$, respectively

High $=125,45$ and $48 \mathrm{~kg} \mathrm{fed}^{-1}$ of $\mathrm{N}, \mathrm{P}$ and $\mathrm{K}$, respectively 
1000 kernel weight (g)

Exhibited data in Table 4 denote that salicylic acid, NPK fertilization and their interaction had a significant effect on 1000 kernel weight in the two growing seasons. All tested salicylic acid concentrations surpassed control treatment in this respect in favor of $150 \mathrm{ppm}$ concentration which produced the heaviest kernels (39.83 and $35.90 \mathrm{~g}$ in the first and second seasons, respectively). This is may be due to the exogenous application of SA may participate in the regulation of physiological processes in plants, such as stomata closure, ion uptake and transport membrane permeability and photosynthesis and growth (Raskin, 1992 and Gunes et al., 2007). Also, the heaviest kernels were obtained from wheat plants fertilized by high NPK fertilization rate while the lightest kernels (34.48 and $32.38 \mathrm{~g}$ in the first and second seasons, respectively) were obtained from low NPK fertilization rate. These findings are in a good line with those obtained by Hussain et al. (2002), Rehman et al. (2008) and Leghari et al. (2016). Moreover, the highest mean values of 1000 kernel weight (42.50 and $36.70 \mathrm{~g}$ in the first and second seasons, respectively) were recorded from bread wheat plants sprayed by $150 \mathrm{ppm}$ salicylic acid and fertilized by high NPK fertilization rate.

Table 4. Effect of salicylic acid, NPK fertilizations and their interaction on 1000 kernel weight (g)

\begin{tabular}{|c|c|c|c|c|c|c|c|c|c|c|}
\hline Seasons & \multicolumn{5}{|c|}{ 2013-2014 } & \multicolumn{5}{|c|}{ 2014-2015 } \\
\hline Salicylic acid NPK & 0 & 50 & 100 & 150 & Mean & 0 & 50 & 100 & 150 & Mean \\
\hline Low & 30.00 & 34.40 & 35.50 & 38.00 & 34.48 & 29.00 & 32.00 & 33.50 & 35.00 & 32.38 \\
\hline Recommended & 35.00 & 35.00 & 39.50 & 39.00 & 37.13 & 33.00 & 34.00 & 34.90 & 36.00 & 34.48 \\
\hline High & 35.50 & 39.00 & 41.00 & 42.50 & 39.50 & 34.00 & 34.60 & 35.00 & 36.70 & 35.08 \\
\hline Mean & 33.50 & 36.13 & 38.67 & 39.83 & ------ & 32.00 & 33.53 & 34.47 & 35.90 & ----- \\
\hline $\begin{array}{l}\text { F test and } \\
\text { LSD }_{0.05} \text { value }\end{array}$ & \multicolumn{3}{|c|}{ F test } & \multicolumn{2}{|c|}{ LSD } & \multicolumn{3}{|c|}{$F$ test } & \multicolumn{2}{|c|}{ LSD } \\
\hline $\mathrm{SA}$ & \multicolumn{3}{|c|}{$*$} & \multicolumn{2}{|c|}{1.20} & \multicolumn{3}{|c|}{$* *$} & \multicolumn{2}{|c|}{0.80} \\
\hline NPK & \multicolumn{3}{|c|}{$* *$} & \multicolumn{2}{|c|}{0.91} & \multicolumn{3}{|c|}{$* *$} & \multicolumn{2}{|c|}{0.71} \\
\hline SA*NPK & \multicolumn{3}{|c|}{$*$} & \multicolumn{2}{|c|}{1.50} & \multicolumn{3}{|c|}{$*$} & \multicolumn{2}{|c|}{1.20} \\
\hline
\end{tabular}

Where, $*, * *$ mean significant at 5 and $1 \%$ level of significant, respectively

Low $=75,15$ and $24 \mathrm{~kg} \mathrm{fed}^{-1}$ of $\mathrm{N}, \mathrm{P}$ and $\mathrm{K}$, respectively

Recommended $=100,30$ and $36 \mathrm{~kg} \mathrm{fed}^{-1}$ of $\mathrm{N}, \mathrm{P}$ and K, respectively

High $=125,45$ and $48 \mathrm{~kg} \mathrm{fed}^{-1}$ of $\mathrm{N}, \mathrm{P}$ and $\mathrm{K}$, respectively

Kernels weight spike ${ }^{-1}(\mathrm{~g})$

The kernels weight spike ${ }^{-1}$ trait affected significantly by tested variables and their interaction in the two growing seasons (Table 5). Wheat plants sprayed by salicylic acid gained significant kernels weight spike $^{-1}$ as compared to control treatment (without salicylic). Thus, high salicylic acid concentration (150 ppm) recorded the highest mean values in this respect $(2.67$ and $2.53 \mathrm{~g}$ in the first and second seasons, respectively). This is to be logic since the same salicylic acid concentration give the highest mean values with regard to number of kernels spike ${ }^{-1}$ and 1000 kernel weight and consequently produced the highest mean values of kernels weight spike ${ }^{-1}$. These results are in harmony with that obtained by Ibrahim et al. (2014). Furthermore, the high NPK fertilization rate registered the maximum mean values of 
kernels weight spike $^{-1} \quad(2.60$ and $2.38 \mathrm{~g}$ in the first and second seasons, respectively). This is to be expected since the same NPK fertilization rate gained the highest mean values with regard to number of kernel spike ${ }^{-1}$ and 1000 kernels weight and consequently give the maximum mean values of kernels weight spike ${ }^{-1}$. Similar trend was observed by Rehman et al. (2008) and Ibrahim et al (2014). Here too, the highest mean values of kernels weight spike ${ }^{-1}$ (3.00 and 2.70g in the first and second seasons, respectively) were registered from wheat plants sprayed by $150 \mathrm{ppm}$ salicylic acidand fertilized by high NPK fertilization rate.

Table 5. Effect of salicylic acid, NPK fertilizations and their interaction on kernels weight spike ${ }^{-1}$

\begin{tabular}{|c|c|c|c|c|c|c|c|c|c|c|}
\hline Seasons & \multicolumn{5}{|c|}{ 2013-2014 } & \multicolumn{5}{|c|}{ 2014-2015 } \\
\hline Salicylic acid NPK & 0 & 50 & 100 & 150 & Mean & 0 & 50 & 100 & 150 & Mean \\
\hline Low & 1.95 & 2.04 & 2.19 & 2.40 & 2.15 & 1.65 & 1.70 & 2.10 & 2.40 & 1.96 \\
\hline Recommended & 2.00 & 2.33 & 2.43 & 2.60 & 2.34 & 1.75 & 1.90 & 2.30 & 2.50 & 2.11 \\
\hline High & 2.28 & 2.50 & 2.60 & 3.00 & 2.60 & 2.00 & 2.30 & 2.50 & 2.70 & 2.38 \\
\hline Mean & 2.08 & 2.29 & 2.41 & 2.67 & ---- & 1.80 & 1.97 & 2.30 & 2.53 & ----- \\
\hline $\begin{array}{l}\text { F test and } \\
\text { LSD }_{0.05} \text { value }\end{array}$ & \multicolumn{3}{|c|}{$F$ test } & \multicolumn{2}{|c|}{ LSD } & \multicolumn{3}{|c|}{$F$ test } & \multicolumn{2}{|c|}{ LSD } \\
\hline SA & \multicolumn{3}{|c|}{ * } & \multicolumn{2}{|c|}{0.21} & \multicolumn{3}{|c|}{$* *$} & \multicolumn{2}{|c|}{0.15} \\
\hline NPK & \multicolumn{3}{|c|}{$*$} & \multicolumn{2}{|c|}{0.25} & \multicolumn{3}{|c|}{ * } & \multicolumn{2}{|c|}{0.22} \\
\hline SA*NPK & \multicolumn{3}{|c|}{$*$} & \multicolumn{2}{|c|}{0.30} & \multicolumn{3}{|c|}{ * } & \multicolumn{2}{|c|}{0.27} \\
\hline
\end{tabular}

Where, $* * *$ mean significant at 5 and $1 \%$ level of significant, respectively

Low $=75,15$ and $24 \mathrm{~kg} \mathrm{fed}^{-1}$ of $\mathrm{N}, \mathrm{P}$ and $\mathrm{K}$, respectively

Recommended $=100,30$ and $36 \mathrm{~kg} \mathrm{fed}^{-1}$ of $\mathrm{N}, \mathrm{P}$ and $\mathrm{K}$, respectively

High $=125,45$ and $48 \mathrm{~kg} \mathrm{fed}^{-1}$ of N, P and K, respectively

C-Biological, grain and straw yields $\left(\mathrm{kg} \mathrm{fed}^{-1}\right)$ :

\section{Biological yield}

Data presented in Table 6 reveal that salicylic acid, NPK fertilization rate and their interaction had a significant influence on biological yield in both seasons. Thus, sprayed wheat plants by salicylic acid increased significantly biological yield as compared to control treatment in favor to high salicylic acid concentration (150 ppm) which increasedbiological yieldin the first seasonby the rate of $31.07,12.13$ and $7.45 \%$ from 0.00 (control), 50 and 100 ppm salicylic acid concentrations, respectively, being 28.36, 11.02 and 6.83 in the second season in the same order. These findings can be explained by the superiority of high salicylic acid concentration $(150 \mathrm{ppm})$ with regard to plant height and kernels weight spike $^{-1}$ traits which considered the main consist of biological yield. These results are in a good line with those reported by Raskin (1992) and Gunes et al. (2007). Also, wheat plants fertilized by high NPK fertilization rate produced the maximum biological yield $(5600$ and $5035 \mathrm{~kg}$ $\mathrm{fed}^{-1}$ in the first and second seasons, respectively). This is to be logic since the same NPK fertilization rate give the highest mean values with regard to plant height and kernels weight spike $^{-1}$. These findings are harmony with those obtained by Rehman et al. (2008) and Ibrahim et al (2014). Moreover, sprayed wheat plants by $150 \mathrm{ppm}$ salicylic acid with high NPK fertilization rate produced the maximum biological yield (6300 and $5614 \mathrm{~kg} \mathrm{fed}^{-1}$ in the first and second seasons, respectively). 
Table 6. Effect of salicylic acid, NPK fertilizations and their interaction on biological yield ( $\left.\mathrm{kg} \mathrm{fed}^{-1}{ }^{-1}\right)$

\begin{tabular}{|c|c|c|c|c|c|c|c|c|c|c|}
\hline Seasons & \multicolumn{5}{|c|}{ 2013-2014 } & \multicolumn{5}{|c|}{ 2014-2015 } \\
\hline Salicylic acid NPK & 0 & 50 & 100 & 150 & Mean & 0 & 50 & 100 & 150 & Mean \\
\hline Low & 3800 & 4950 & 5000 & 5300 & 4763 & 3398 & 4449 & 4500 & 4608 & 4239 \\
\hline Recommended & 4400 & 5080 & 5400 & 5700 & 5145 & 4096 & 4566 & 4850 & 5217 & 4682 \\
\hline High & 5000 & 5400 & 5700 & 6300 & 5600 & 4533 & 4891 & 5100 & 5614 & 5035 \\
\hline Mean & 4400 & 5143 & 5367 & 5767 & ----- & 4009 & 4635 & 4817 & 5146 & --- \\
\hline $\begin{array}{l}\mathrm{F} \text { test and } \mathrm{LSD}_{0.05} \\
\text { value }\end{array}$ & \multicolumn{3}{|c|}{ F test } & \multicolumn{2}{|c|}{ LSD } & \multicolumn{3}{|c|}{ F test } & \multicolumn{2}{|c|}{ LSD } \\
\hline SA & \multicolumn{3}{|c|}{$*$} & \multicolumn{2}{|c|}{150.00} & \multicolumn{3}{|c|}{$* *$} & \multicolumn{2}{|c|}{120.20} \\
\hline NPK & \multicolumn{3}{|c|}{ * } & \multicolumn{2}{|c|}{110.00} & \multicolumn{3}{|c|}{$* *$} & \multicolumn{2}{|c|}{101.2} \\
\hline SA*NPK & \multicolumn{3}{|c|}{$* *$} & \multicolumn{2}{|c|}{175.20} & \multicolumn{3}{|c|}{$* *$} & \multicolumn{2}{|c|}{130.0} \\
\hline
\end{tabular}

Where, $*, * *$ mean significant at 5 and $1 \%$ level of significant, respectively

Low $=75,15$ and $24 \mathrm{~kg} \mathrm{fed}^{-1}$ of $\mathrm{N}, \mathrm{P}$ and $\mathrm{K}$, respectively

Recommended $=100,30$ and $36 \mathrm{~kg} \mathrm{fed}^{-1}$ of $\mathrm{N}, \mathrm{P}$ and $\mathrm{K}$, respectively

High $=125,45$ and $48 \mathrm{~kg} \mathrm{fed}^{-1}$ of $\mathrm{N}, \mathrm{P}$ and $\mathrm{K}$, respectively

\section{Grain yield}

Exhibited data in Table 7 show that salicylic acid, NPK fertilizationand their interaction had a significant effect on grain yield in the two growing seasons. Increasing salicylic acid concentration from zero to 150 ppm increased significantly grain yield from 1583 to $2200 \mathrm{~kg} \mathrm{fed}^{-1}$ in the first season and from 1517to 2153 $\mathrm{kg} \mathrm{fed}^{-1}$ in the second one. This is to be logic since the same trend was observed with regard to kernel weight spike $^{-1}$. These results are in a good line with those reported by Raskin (1992) and Gunes et al. (2007). Furthermore, wheat plants fertilized by the high rate of NPK fertilization produced the highest mean values of grain yield (2188 and $2114 \mathrm{~kg} \mathrm{fed}^{-1}$ in the first and second seasons, respectively). This is to be expected since the same NPK fertilization rate registered the highest mean values with regard to kernels weight spike and consequently produced the highest mean values of grain yield in both seasons. These results are in harmony with those obtained by Rehman et al. (2008) and Ibrahim et al (2014). Here too, the highest mean values of grain yield (2600 and $2520 \mathrm{~kg} \mathrm{fed}^{-1}$ in the first and second seasons, respectively) were recorded from wheat plants sprayed by $150 \mathrm{ppm}$ salicylic acid with high NPK fertilization rate.

Table 7. Effect of salicylic acid, NPK fertilizations and their interaction on grain yield (kg fed. $\left.{ }^{-1}\right)$

\begin{tabular}{|c|c|c|c|c|c|c|c|c|c|c|}
\hline Seasons & \multicolumn{5}{|c|}{ 2013-2014 } & \multicolumn{5}{|c|}{ 2014-2015 } \\
\hline Salicylic acid NPK & 0 & 50 & 100 & 150 & Mean & 0 & 50 & 100 & 150 & Mean \\
\hline Low & 1300 & 1600 & 1750 & 1900 & 1638 & 1250 & 1530 & 1720 & 1860 & 1590 \\
\hline Recommended & 1600 & 1800 & 2040 & 2100 & 1885 & 1520 & 1760 & 2010 & 2080 & 1843 \\
\hline High & 1850 & 2100 & 2200 & 2600 & 2188 & 1780 & 2000 & 2155 & 2520 & 2114 \\
\hline Mean & 1583 & 1833 & 1997 & 2200 & ---- & 1517 & 1763 & 1962 & 2153 & ---- \\
\hline $\begin{array}{l}\text { F test and } \mathrm{LSD}_{0.05} \\
\text { value }\end{array}$ & \multicolumn{3}{|c|}{$\mathrm{F}$ test } & \multicolumn{2}{|c|}{ LSD } & \multicolumn{3}{|c|}{$\mathrm{F}$ test } & \multicolumn{2}{|c|}{ LSD } \\
\hline SA & \multicolumn{3}{|c|}{$*$} & \multicolumn{2}{|c|}{55.77} & \multicolumn{3}{|c|}{$* *$} & \multicolumn{2}{|c|}{50.90} \\
\hline NPK & \multicolumn{3}{|c|}{$*$} & \multicolumn{2}{|c|}{45.90} & \multicolumn{3}{|c|}{$* *$} & \multicolumn{2}{|c|}{43.20} \\
\hline SA*NPK & \multicolumn{3}{|c|}{$* *$} & \multicolumn{2}{|c|}{70.90} & \multicolumn{3}{|c|}{$* *$} & \multicolumn{2}{|c|}{67.90} \\
\hline
\end{tabular}

Where, *,** mean significant at 5 and $1 \%$ level of significant, respectively

Low $=75,15$ and $24 \mathrm{~kg} \mathrm{fed}^{-1}$ of $\mathrm{N}, \mathrm{P}$ and $\mathrm{K}$, respectively

Recommended $=100,30$ and $36 \mathrm{~kg} \mathrm{fed}^{-1}$ of $\mathrm{N}, \mathrm{P}$ and $\mathrm{K}$, respectively

High $=125,45$ and $48 \mathrm{~kg} \mathrm{fed}^{-1}$ of $\mathrm{N}, \mathrm{P}$ and $\mathrm{K}$, respectively 


\section{Straw yield}

Straw yield traits was affected significantly by the tested factors and their interaction in both seasons (Table 8). The presented data focus that all tested salicylic acid concentration surpassed the control treatment (without salicylic) in this respect in favor of high salicylic acid concentration $(150 \mathrm{ppm})$ which produced the highest mean values of straw yield (3567 and $2993 \mathrm{~kg} \mathrm{fed}^{-1}$ in the first and second seasons, respectively). The amount of increment in straw yield reached about 26.62, 7.76 and $5.85 \%$ as compared to zero, 50 and $100 \mathrm{ppm}$ of salicylic acid concentrations in the first season, being 20.10, 4.21 and $4.83 \%$ in the second season in the same order. This is to be expected since the same trend was obtained regarding biological yield. These results are confirmed with those obtained by Raskin (1992) and Gunes et al. (2007). Also, straw yield was increased with increasing NPK fertilization rate in both seasons. This is to be logic since the same trend was observed regarding biological yield. These results are in harmony with those obtained by Rehman et al. (2008) and Ibrahim et al (2014). Here, too the highest mean values of straw yield (3700 and $3094 \mathrm{~kg} \mathrm{fed}^{-1}$ in the first and second seasons, respectively) were obtained from wheat plants sprayed by $150 \mathrm{ppm}$ salicylic acid and fertilized by high NPK rate.

Table 8. Effect of salicylic acid, NPK fertilizations and their interaction on straw yield (kg fed. ${ }^{-1}$ )

\begin{tabular}{|c|c|c|c|c|c|c|c|c|c|c|}
\hline Seasons & \multicolumn{5}{|c|}{ 2013-2014 } & \multicolumn{5}{|c|}{ 2014-2015 } \\
\hline Salicylic acid NPK & 0 & 50 & 100 & 150 & Mean & 0 & 50 & 100 & 150 & Mean \\
\hline Low & 2500 & 3350 & 3250 & 3400 & 3125 & 2148 & 2919 & 2780 & 2748 & 2649 \\
\hline Recommended & 2800 & 3280 & 3360 & 3600 & 3260 & 2576 & 2806 & 2840 & 3137 & 2839 \\
\hline High & 3150 & 3300 & 3500 & 3700 & 3412 & 2753 & 2891 & 2945 & 3094 & 2921 \\
\hline Mean & 2817 & 3310 & 3370 & 3567 & ----- & 2492 & 2872 & 2855 & 2993 & ---- \\
\hline $\mathrm{F}$ test and $\mathrm{LSD}_{0.05}$ & \multicolumn{3}{|c|}{$\mathrm{F}$ test } & \multicolumn{2}{|c|}{ LSD } & \multicolumn{3}{|c|}{ F test } & \multicolumn{2}{|c|}{ LSD } \\
\hline SA & \multicolumn{3}{|c|}{$*$} & \multicolumn{2}{|l|}{60.60} & \multicolumn{3}{|c|}{$* *$} & \multicolumn{2}{|l|}{57.90} \\
\hline NPK & \multicolumn{3}{|c|}{$*$} & \multicolumn{2}{|l|}{56.90} & \multicolumn{3}{|c|}{$* *$} & \multicolumn{2}{|l|}{53.30} \\
\hline SA*NPK & \multicolumn{3}{|c|}{$* *$} & \multicolumn{2}{|l|}{78.80} & \multicolumn{3}{|c|}{$* *$} & \multicolumn{2}{|l|}{77.70} \\
\hline
\end{tabular}

Where, $* * *$ mean significant at 5 and $1 \%$ level of significant, respectively

Low $=75,15$ and $24 \mathrm{~kg} \mathrm{fed}^{-1}$ of $\mathrm{N}, \mathrm{P}$ and $\mathrm{K}$, respectively

Recommended $=100,30$ and $36 \mathrm{~kg} \mathrm{fed}^{-1}$ of $\mathrm{N}, \mathrm{P}$ and $\mathrm{K}$, respectively

High $=125,45$ and $48 \mathrm{~kg} \mathrm{fed}^{-1}$ of $\mathrm{N}, \mathrm{P}$ and $\mathrm{K}$, respectively

Nitrogen, Phosphorus and Potassium use efficiency $(\mathrm{Kg} / \mathrm{Kg})$

Nitrogen use efficiency (NUE)

Data exhibited in Table 9 reveal that salicylic acid, NPK fertilization and their interaction had a significant influence on the NUE in the two growing seasons. Increasing salicylic acid concentration from zero to 150 ppm increased NUE from 16.04 to 22.38 in the first season and from 15.37 to 21.92 in the second one.
This is to be logic since the same trend was observed with regard to grain yield. Also, the data state that increasing NPK fertilizer decreased NUE significantly in both seasons although high nitrogen rate generally led to higher yield.Thus, the highest NUE values $(21.84$ and $21.20 \mathrm{~kg}$ grain $/ \mathrm{kg} \mathrm{N}$ applied in the first and second seasons, respectively) were obtained when nitrogen fertilizer was applied by low amount while, the 
lowest NUE values $(17.50$ and $16.91 \mathrm{~kg}$ grain $/ \mathrm{kg} \mathrm{N}$ applied in the first and second seasons, respectively) were recorded from high nitrogen fertilizer rate. The result is consistent with that of Dhugga and Waines (1989), Ortiz-Monasterio et al. (1997) Roberts (2008) and Haile et al. (2012) who found significant decreases in NUE with increasing rates of $\mathrm{N}$ application. Here too, wheat plants sprayed by high salicylic acid concentration $(150 \mathrm{ppm})$ and subjected to low NPK fertilization rate produced the maximum mean values of NUE which reached 25.33 and $24.80 \mathrm{~kg}$ grain $/ \mathrm{kg} \mathrm{N}$ applied in the first and second seasons, respectively. This is logic since the same interaction produced the highest mean values with regard to grain yield and consequently produced the highest mean values of NUE.

Table 9. Effect of salicylic acid, NPK fertilizations and their interaction on nitrogen use efficiency (NUE)

\begin{tabular}{|c|c|c|c|c|c|c|c|c|c|c|}
\hline Seasons & \multicolumn{5}{|c|}{ 2013-2014 } & \multicolumn{5}{|c|}{ 2014-2015 } \\
\hline Salicylic acid NPK & 0 & 50 & 100 & 150 & Mean & 0 & 50 & 100 & 150 & Mean \\
\hline Low & 17.33 & 21.33 & 23.33 & 25.33 & 21.84 & 16.67 & 20.40 & 22.93 & 24.80 & 21.20 \\
\hline Recommended & 16.00 & 18.00 & 20.40 & 21.00 & 18.85 & 15.20 & 17.60 & 20.10 & 20.80 & 18.43 \\
\hline High & 14.80 & 16.80 & 17.60 & 20.80 & 17.50 & 14.24 & 16.00 & 17.24 & 20.16 & 16.91 \\
\hline Mean & 16.04 & 18.71 & 20.44 & 22.38 & ----- & 15.37 & 18.00 & 20.09 & 21.92 & ---- \\
\hline $\begin{array}{l}\text { F test and } \mathrm{LSD}_{0.05} \\
\text { value }\end{array}$ & \multicolumn{3}{|c|}{$\mathrm{F}$ test } & \multicolumn{2}{|c|}{ LSD } & \multicolumn{3}{|c|}{$\mathrm{F}$ test } & \multicolumn{2}{|c|}{ LSD } \\
\hline SA & \multicolumn{3}{|c|}{ * } & \multicolumn{2}{|l|}{2.13} & \multicolumn{3}{|c|}{ * } & \multicolumn{2}{|l|}{1.70} \\
\hline NPK & \multicolumn{3}{|c|}{ * } & \multicolumn{2}{|l|}{2.06} & \multirow{2}{*}{\multicolumn{3}{|c|}{$*$}} & \multicolumn{2}{|l|}{1.65} \\
\hline SA*NPK & \multicolumn{3}{|c|}{ * } & \multicolumn{2}{|l|}{2.66} & & & & \multicolumn{2}{|l|}{1.90} \\
\hline
\end{tabular}

Where, *mean significant at $5 \%$ level of significant Low $=75,15$ and $24 \mathrm{~kg} \mathrm{fed}^{-1}$ of $\mathrm{N}, \mathrm{P}$ and $\mathrm{K}$, respectively Recommended $=100,30$ and $36 \mathrm{~kg} \mathrm{fed}^{-1}$ of $\mathrm{N}, \mathrm{P}$ and $\mathrm{K}$, respectively $\mathrm{High}=125,45$ and $48 \mathrm{~kg} \mathrm{fed}^{-1}$ of N, P and K, respectively

Phosphorus use efficiency (PUE)

Presented data in Table 10 reveal that salicylic acid, NPK fertilization and their interaction had a significant effect on PUE in the two growing seasons. Salicylic acid enhancement PUE as compared to control treatment (without salicylic acid) in favor of $150 \mathrm{ppm}$ concentration which gained the maximum PUE (84.81 and $83.11 \mathrm{~kg}$ grain/ kg P applied in the first and second seasons, respectively). This is to be logic since the same salicylic acid concentration give the highest mean values regarding grain yield $\mathrm{fed}^{-1}$ trait and consequently produced the highest PUE mean values. Furthermore, increasing NPK fertilizer rate consider the major reason for decreasing PUE although, the same NPK rate gained the highest mean values of grain yield. Thus, the maximum PUE mean values (109.20 and $106.00 \mathrm{~kg}$ grain/ $\mathrm{kg} \mathrm{P}$ applied in the first and second seasons, respectively) were registered when NPK fertilizers were applied at the low rate. This is may be due to the leaching accord when the high fertilizers rate was applied led to decreasing in PUE. Moreover, the wheat plants sprayed by high salicylic acid concentration $(150 \mathrm{ppm})$ and subjected to low NPK fertilization rate gained the maximum mean values of PUE (126.67 and $124.00 \mathrm{~kg}$ grain/ $\mathrm{kg} P$ applied in the first and second seasons, respectively). The previous 
findings could be explained by the high grain yield produced under the same interaction which led to high PUE.

Table 10. Effect of salicylic acid, NPK fertilizations and their interaction on phosphorus use efficiency(PUE)

\begin{tabular}{|c|c|c|c|c|c|c|c|c|c|c|}
\hline Seasons & \multicolumn{5}{|c|}{ 2013-2014 } & \multicolumn{5}{|c|}{ 2014-2015 } \\
\hline Salicylic acid NPK & 0 & 50 & 100 & 150 & Mean & 0 & 50 & 100 & 150 & Mean \\
\hline Low & 86.67 & 106.67 & 116.67 & 126.67 & 109.20 & 83.33 & 102.00 & 114.67 & 124.00 & 106.00 \\
\hline Recommended & 53.33 & 60.00 & 68.00 & 70.00 & 62.83 & 50.67 & 58.67 & 67.00 & 69.33 & 61.43 \\
\hline High & 41.11 & 46.67 & 48.89 & 57.78 & 48.62 & 39.56 & 44.44 & 47.89 & 56.00 & 46.98 \\
\hline Mean & 60.37 & 71.11 & 77.85 & 84.81 & ----- & 57.85 & 68.37 & 76.52 & 83.11 & ----- \\
\hline $\begin{array}{l}\text { F test and } \mathrm{LSD}_{0.05} \\
\text { value }\end{array}$ & \multicolumn{3}{|c|}{ F test } & \multicolumn{2}{|c|}{ LSD } & \multicolumn{3}{|c|}{ F test } & \multicolumn{2}{|c|}{ LSD } \\
\hline SA & \multicolumn{3}{|c|}{$*$} & \multicolumn{2}{|c|}{3.30} & \multicolumn{3}{|c|}{$*$} & \multicolumn{2}{|c|}{3.25} \\
\hline NPK & \multicolumn{3}{|c|}{$*$} & \multicolumn{2}{|c|}{3.00} & \multicolumn{3}{|c|}{$*$} & \multicolumn{2}{|c|}{2.87} \\
\hline SA*NPK & \multicolumn{3}{|c|}{$*$} & \multicolumn{2}{|c|}{6.15} & \multicolumn{3}{|c|}{$*$} & \multicolumn{2}{|c|}{5.56} \\
\hline
\end{tabular}

Where, *mean significant at $5 \%$ level of significant

Low $=75,15$ and $24 \mathrm{~kg} \mathrm{fed}^{-1}$ of $\mathrm{N}, \mathrm{P}$ and $\mathrm{K}$, respectively

Recommended $=100,30$ and $36 \mathrm{~kg} \mathrm{fed}^{-1}$ of $\mathrm{N}, \mathrm{P}$ and $\mathrm{K}$, respectively

High $=125,45$ and $48 \mathrm{~kg} \mathrm{fed}^{-1}$ of N, P and K, respectively

\section{Potassium use efficiency (KUE)}

Potassium use efficiency (KUE) trait was affected significantly by salicylic acid, NPK fertilization and their interaction in both seasons (Table 11). All tested salicylic acid concentrations surpassed control treatment in this respect. Furthermore, the tested salicylic acid concentrations varied significantly in favor of high salicylic acid concentration (150 $\mathrm{ppm}$ ) which gained the maximum mean values of KUE (63.89 and $62.59 \mathrm{~kg}$ grain $/ \mathrm{kg} \mathrm{K}$ applied in the first and second seasons, respec- tively). This is to be expected since the same salicylic acid concentration produced the highest mean values of grain yield and consequently gained the maximum mean values of KUE. Also. The data show that increasing NPK fertilization rate resulted in decreasing in KUE in both seasons. Here too, the wheat plants sprayed by $150 \mathrm{ppm}$ salicylic acid and fertilized by low rate of NPK fertilizers gained the highest mean values of KUE (79.17 and $77.50 \mathrm{~kg}$ grain $/ \mathrm{kg} \mathrm{K}$ applied in the first and second seasons, respectively).

Table 11. Effect of salicylic acid, NPK fertilizations and their interaction on potassium use efficiency(KUE)

\begin{tabular}{|c|c|c|c|c|c|c|c|c|c|c|}
\hline Seasons & \multicolumn{5}{|c|}{ 2013-2014 } & \multicolumn{5}{|c|}{ 2014-2015 } \\
\hline Salicylic acid NPK & 0 & 50 & 100 & 150 & Mean & 0 & 50 & 100 & 150 & Mean \\
\hline Low & 54.17 & 66.67 & 72.92 & 79.17 & 68.25 & 52.08 & 63.75 & 71.67 & 77.50 & 66.25 \\
\hline Recommended & 44.44 & 50.00 & 56.67 & 58.33 & 52.36 & 42.22 & 48.89 & 55.83 & 57.78 & 51.19 \\
\hline High & 38.54 & 43.75 & 45.83 & 54.17 & 45.58 & 37.08 & 41.67 & 44.90 & 52.50 & 44.04 \\
\hline Mean & 45.72 & 53.47 & 58.47 & 63.89 & ----- & 43.80 & 51.44 & 57.47 & 62.59 & ----- \\
\hline $\begin{array}{l}\text { F test and } \mathrm{LSD}_{0.05} \\
\text { value }\end{array}$ & \multicolumn{3}{|c|}{$\mathrm{F}$ test } & \multicolumn{2}{|c|}{ LSD } & \multicolumn{3}{|c|}{ F test } & \multicolumn{2}{|c|}{ LSD } \\
\hline SA & \multicolumn{3}{|c|}{ * } & \multicolumn{2}{|c|}{2.80} & \multicolumn{3}{|c|}{ * } & \multicolumn{2}{|c|}{2.75} \\
\hline NPK & \multicolumn{3}{|c|}{ * } & \multicolumn{2}{|c|}{2.55} & \multirow{2}{*}{\multicolumn{3}{|c|}{ * }} & \multicolumn{2}{|c|}{2.35} \\
\hline SA*NPK & \multicolumn{3}{|c|}{ * } & \multicolumn{2}{|c|}{5.40} & & & & \multicolumn{2}{|c|}{5.00} \\
\hline
\end{tabular}

Where, *mean significant at $5 \%$ level of significant

Low $=75,15$ and $24 \mathrm{~kg} \mathrm{fed}^{-1}$ of $\mathrm{N}, \mathrm{P}$ and $\mathrm{K}$, respectively

Recommended $=100,30$ and $36 \mathrm{~kg} \mathrm{fed}^{-1}$ of N, P and K, respectively

$\mathrm{High}=125,45$ and $48 \mathrm{~kg} \mathrm{fed}^{-1}$ of N, P and K, respectively 
References

Al-Hakimi, A.M.A. and A.M. Hamada (2001). Counteraction of salinity stress on wheat plants by grain soaking in ascorbic acid, thiamine or sodium salicylate. - Biol. Plant. 44: 253-261, 2001.

Ali, E.A. (2010). Grain yield and nitrogen use efficiency of pearl millet as affected by plant density, nitrogen rate and splitting in sandy soil. American-Eurasian J. Agric. \& Environ. Sci., 7(3): 327-335.

Borsani, O., V. Valpuesta and M.A. Botella (2001). Effect of salicylic Acid on the evidence for a role of salicylic acid in the growth, photosynthesis and carbohydrate oxidative damage generated by $\mathrm{NaCl}$ and osmotic metabolism in saltstressed maize plants. Plant Physiol. 126: 1024 -1030.

Dhugga, K.S. and J.G. Waines (1989). Analysis of nitrogen accumulation and use in bread and durum wheat. Crop Sci. 29, 1232-1239.

Gomez K.A. and A.A. Gomez (1984). Statistical Procedures For Agriculture Research. A Wiley - Inter Science Publication, John wiley sons, lnc. New York, USA.

Gunes, A., A. Inal, M. Alpaslan, F. Eraslan, E.G. Bagci and N. Cicek (2007). Salicylic acid induced changes on some physiological parameters symptomatic for oxidative stress and mineral nutrition in maize (Zea mays L.) grown under salinity, J. of Plant Physiol, 164 Issues 6: 728-736.

Haile D., D. Nigussie and A. Ayana (2012). Nitrogen use efficiency of bread wheat: Effects of nitrogen rate and time of application. J. Soil Sci. Plant Nutr. 12 (3), 389-410.

Hussain M.I., S.H. Shah, S. Hussain and I. khalid (2002). Growth, Yield and Quality Response of Three Wheat (Triticumaestivum L.) Varieties to Different Levels of $\mathrm{N}, \mathrm{P}$ and K. Int. J. Agri. Biol., Vol. 4, No. 3,362-364.

Ibrahim, O.M., A.B. Bakry, A.T. Thalooth and M.F. El -Karamany (2014). Influence of Nitrogen Fertilizer and Foliar Application of Salicylic Acid on Wheat. Agric. Sci., 5, 1316-1321.

Leghari A.H., G.M. Laghari, M.A. Ansari, M.A. Mirjat, U.A. Laghari, S.J. Leghari, Ab.H. Laghari, Z.A. Abbasi (2016). Effect of NPK and Boron on Growth and Yield of Wheat Variety TJ-83 at Tandojam Soil. Adv. in Environ. Biol., 10(10) Pages: 209-216.

Ortiz-Monasterio, J.I., K.D. Sayre, S. Rajaram and M. Mc-Mahon (1997). Genetic progress in wheat yield and nitrogen use efficiency under four nitrogen rates. Crop Science. 37, 898-904.

Petkov, M.(1983). Effect of increasing fertilization rates on grain yield quality of winter soft wheat cultivars. Soils and Fert., 45: 7222.

Raskin, I.(1992). Role of salicylic acid in plants. Annual Review of Plant Physiology and Plant Molecular Biol. 43: 439-463.

Rehman, S., S. K. Khalil, A. Rehman and A.U.R. Saljoqi (2008). Organic and inorganic fertilizers increase wheat yield components and biomass under rainfed condition. Sarhad J. Agric, 24 ,1,11-20.

Roberts, T.L. (2008). Improving Nutrient Use Efficiency. Turk J. Agric. 32, 177-182.

SAS institute (2008). The SAS System for Windows, release 9.2. Cary NC: SAS institute.

USDA (2017). USDA Gain: Egypt grain and feed annual 2017: Forex availability impacts grain imports. USDA Foreign Agricultural Service, on $15 / 3 / 2017$ https://www.fas.usda.gov/data/grai n-world-markets-and-trade. 
تأثير الرش الورقي بحامض الساليسيليك والتسميد بالنيتروجين والفسفور والبوتاسيوم على إنتاجية محصول القمح

السيد محمود شلبي'، السعدي عبدالحميدعلى'، عصام الدين عبد الهادي عبد اللطيف و وأسماء علي حمد الله'

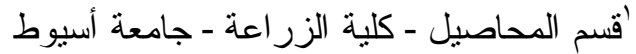

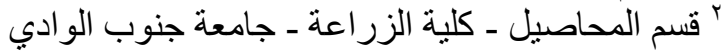

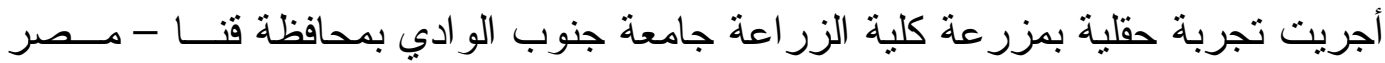

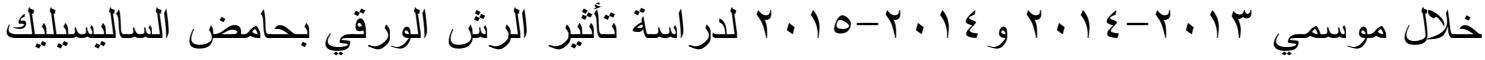

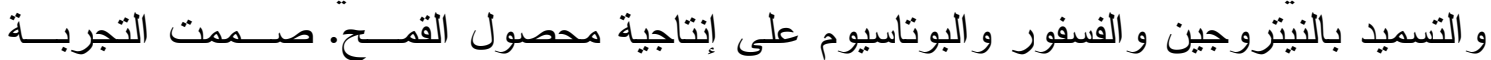

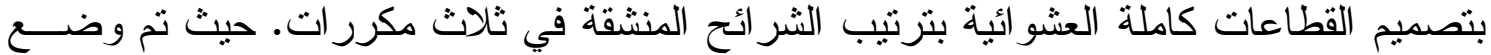

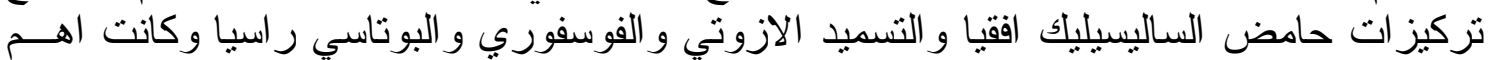

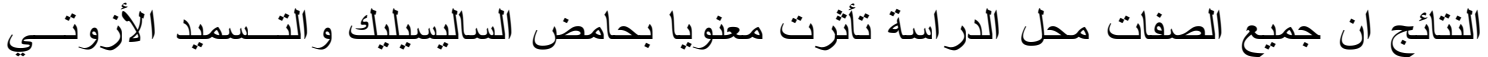

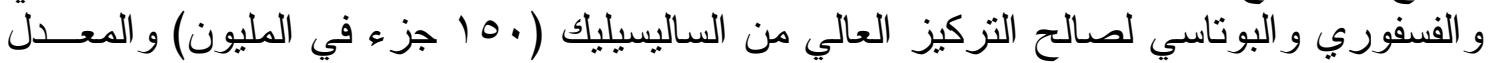

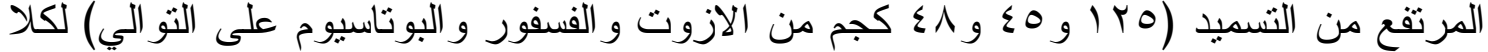

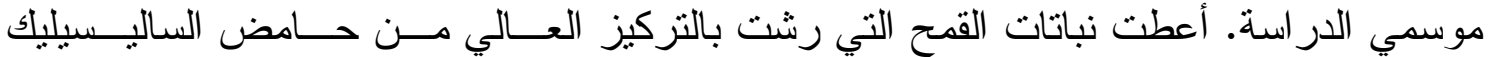

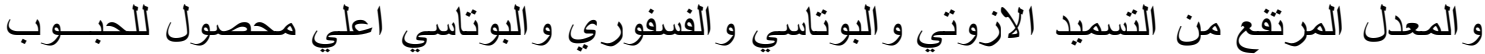

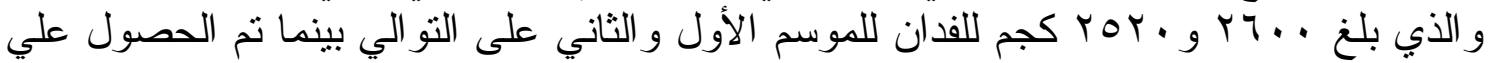
اعلي قيم دن كفاءة استخدام الازوت و الفسفور و البوتاسيوم من نباتات القهح التي رشت بالتركيز

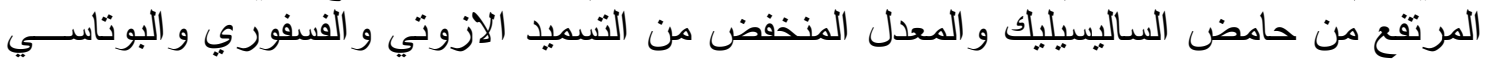
لكلا موسمي الدر استة. 